\title{
Front Matter: Volume 9118
}

, "Front Matter: Volume 9118," Proc. SPIE 9118, Independent Component Analyses, Compressive Sampling, Wavelets, Neural Net, Biosystems, and Nanoengineering XII, 911801 (24 June 2014); doi: 10.1117/12.2072205

SPIE Event: SPIE Sensing Technology + Applications, 2014, Baltimore, MD, United SPIE. States 


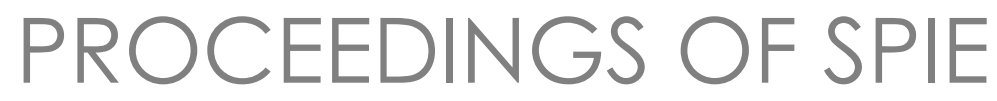

\section{Independent Component Analyses, Compressive Sampling, Wavelets, Neural Net, Biosystems, and Nanoengineering XII}

Harold H. SzU

Liyi Dai

Editors

7-9 May 2014

Baltimore, Maryland, United States

Sponsored and Published by

SPIE 
The papers included in this volume were part of the technical conference cited on the cover and title page. Papers were selected and subject to review by the editors and conference program committee. Some conference presentations may not be available for publication. The papers published in these proceedings reflect the work and thoughts of the authors and are published herein as submitted. The publisher is not responsible for the validity of the information or for any outcomes resulting from reliance thereon.

Please use the following format to cite material from this book:

Author(s), "Title of Paper," in Independent Component Analyses, Compressive Sampling, Wavelets, Neural Net, Biosystems, and Nanoengineering XII, edited by Harold H. Szu, Liyi Dai, Proceedings of SPIE Vol. 9118 (SPIE, Bellingham, WA, 2014) Article CID Number.

ISSN: 0277-786X

ISBN: 9781628410556

Published by

SPIE

P.O. Box 10, Bellingham, Washington 98227-0010 USA

Telephone +1 3606763290 (Pacific Time) · Fax +1 3606471445

SPIE.org

Copyright (C) 2014, Society of Photo-Optical Instrumentation Engineers.

Copying of material in this book for internal or personal use, or for the internal or personal use of specific clients, beyond the fair use provisions granted by the U.S. Copyright Law is authorized by SPIE subject to payment of copying fees. The Transactional Reporting Service base fee for this volume is $\$ 18.00$ per article (or portion thereof), which should be paid directly to the Copyright Clearance Center (CCC), 222 Rosewood Drive, Danvers, MA 01923. Payment may also be made electronically through CCC Online at copyright.com. Other copying for republication, resale, advertising or promotion, or any form of systematic or multiple reproduction of any material in this book is prohibited except with permission in writing from the publisher. The CCC fee code is 0277-786X/14/\$18.00.

Printed in the United States of America.

Publication of record for individual papers is online in the SPIE Digital Library.

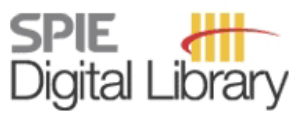

SPIEDigitalLibrary.org

Paper Numbering: Proceedings of SPIE follow an e-First publication model, with papers published first online and then in print and on CD-ROM. Papers are published as they are submitted and meet publication criteria. A unique, consistent, permanent citation identifier (CID) number is assigned to each article at the time of the first publication. Utilization of CIDs allows articles to be fully citable as soon as they are published online, and connects the same identifier to all online, print, and electronic versions of the publication. SPIE uses a six-digit CID article numbering system in which:

- The first four digits correspond to the SPIE volume number.

- The last two digits indicate publication order within the volume using a Base 36 numbering

system employing both numerals and letters. These two-number sets start with 00, 01, 02, 03, 04, $05,06,07,08,09,0 A, 0 B \ldots 0 Z$, followed by 10-1Z, 20-2Z, etc.

The CID Number appears on each page of the manuscript. The complete citation is used on the first page, and an abbreviated version on subsequent pages. Numbers in the index correspond to the last two digits of the six-digit CID Number. 


\section{Contents}

vii Conference Committee
xi Introduction

\section{LARGE DATA ANALYSES PIONEER AWARD}

911802 Large data analysis: automatic visual personal identification in a demography of 1.2 billion persons (Invited Paper) [9118-1]

J. Daugman, Univ. of Cambridge (United Kingdom)

\section{LARGE DATA ANALYSES}

911803 Large data analysis of different sensory modalities [9118-2] M. K. Hsu, The George Washington Univ. (United States); H. Szu, The Catholic Univ. of America (United States)

911804 Non-equilibrium thermodynamics theory of econometric source discovery for large data analysis [9118-3]

R. van Bergem, J. Jenkins, George Mason Univ. (United States); D. Benachenhou, George Washington Univ. (United States); H. Szu, The Catholic Univ. of America (United States)

\section{NANO-ENGINEERING}

911809 Neuromorphic implementation of a software-defined camera that can see through fire and smoke in real-time (Invited Paper) [91 18-7]

J. H. Cha, A. L. Abbott, Virginia Polytechnic Institute and State Univ. (United States);

H. H. Szu, J. Willey, J. Landa, The Catholic Univ. of America (United States); K. A. Krapels,

The Univ. of Memphis (United States)

$91180 \mathrm{~A}$ Theory of enhancing thermal imaging through fire [9118-8]

J. H. Cha, A. L. Abbott, Virginia Polytechnic Institute and State Univ. (United States);

K. A. Krapels, The Univ. of Memphis (United States); H. H. SzU, The Catholic Univ. of America (United States)

9118 OB 3D printed rapid disaster response (Invited Paper) [9118-9]

A. Lacaze, K. Murphy, E. Mottern, K. Corley, Robotic Research LLC (United States);

K.-D. Chu, U.S. Dept. of Homeland Security (United States)

$91180 \mathrm{C}$ Future enhancements to 3D printing and real time production (Invited Paper) [91 18-10] J. Landa, BriarTek, Inc. (United States); J. Jenkins, The Catholic Univ. of America (United States); J. Wu, The George Washington Univ. (United States); H. SzU, The Catholic Univ. of America (United States) 
9118 OE Highway 3D model from image and lidar data (Invited Paper) [9118-12]

J. Chen, H. Chu, X. Sun, Univ. of Louisiana at Lafayette (United States)

\section{PRE-CS VS POST-CS IMAGE PROCESSING}

9118 OG Split Bregman's optimization method for image construction in compressive sensing (Invited Paper) [91 18-26]

D. Skinner, S. Foo, A. Meyer-Baese, Florida State Univ. (United States)

9118 0J Brain order disorder 2nd group report of f-EEG (Invited Paper) [9118-17]

F. Lalonde, N. Gogtay, J. Giedd, N. Vydelingum, National Institutes of Health (United States); D. Brown, U.S. Food and Drug Administration (United States); B. Q. Tran, The Catholic Univ. of America (United States); C. Hsu, M.-K. Hsu, The George Washington Univ. (United States); J. Cha, Virginia Polytechnic Institute and State Univ. (United States); J. Jenkins, The Catholic Univ. of America (United States); L. Ma, J. Willey, J. Wu, K. Oh, The George Washington Univ. (United States); J. Landa, BriarTek, Inc. (United States); C. T. Lin, T. P. Jung, S. Makeig, Univ. of California, San Diego (United States); C. F. Morabito, Univ. Mediterranea di Reggio Calabria (Italy); Q. Moon, Hanyang Univ. (Korea, Republic of); T. Yamakawa, Fuzzy Logic Systems Institute (Japan); S. Y. Lee, KAIST (Korea, Republic of); J. H. Lee, Korea Univ. (Korea, Republic of); H. H. Szu, The Catholic Univ. of America (United States); J. Cha, Virginia Polytechnic Institute and State Univ. (United States); B. Kaur, George Mason Univ. (United States); K. Byrd, Harvard Univ. (United States); K. Dang, Univ. of Virginia (United States); A. Krzywicki, B. O. Familoni, L. Larson, S. Harkrider, K. A. Krapels, The Catholic Univ. of America (United States); L. Dai, Harvard Univ. (United States)

$91180 \mathrm{~K}$ Overcoming shadowing and occlusion in imagery with error-resilient processing (Invited Paper) [9118-18]

C. Hsu, The George Washington Univ. (United States); T. W. DuBosq, Univ. of Central Florida (United States); S. K. Moyer, Georgia Institute of Technology (United States); E. Flug, Univ. of Central Florida (United States); J. Jenkins, George Mason Univ. (United States); J. S. Landa, BriarTek, Inc. (United States); K. Byrd, Harvard Univ. (United States); H. Szu, The Catholic Univ. of America (United States)

\section{UNSUPERVISED LEARNING ICA PIONEER AWARD}

$9118 \mathrm{OL} \quad$ Unsupervised learning toward brain imaging data analysis: cigarette craving and resistance related neuronal activations from functional magnetic resonance imaging data analysis (Invited Paper) [9118-19]

D.-Y. Kim, J.-H. Lee, Korea Univ. (Korea, Republic of)

UNSUPERVISED BRAIN IMAGING

$91180 \mathrm{M}$ User authentication systems based on brain finger-prints (Invited Paper) [9118-20] S.-Y. Lee, E.-S. Jung, KAIST (Korea, Republic of)

$9118 \mathrm{ON} \quad$ Fixing basis mismatch in compressively sampled photonic link [9118-21] J. M. Nichols, F. Bucholtz, C. V. McLaughlin, U.S. Naval Research Lab. (United States);

A. K. Oh, R. M. Willett, Univ. of Wisconsin-Madison (United States) 
9118 OP Low-discrepancy sampling of parametric surface using adaptive space-filling curves (SFC) [91 18-23]

C. Hsu, Trident Systems Inc. (United States); H. Szu, The Catholic Univ. of America (United States)

$91180 Q \quad$ Surface surveillance for ground moving targets indicators [9118-24]

C. Hsu, Trident Systems Inc. (United States); H. Szu, The Catholic Univ. of America (United States)

9118 OR Probabilistic inequalities with applications to machine learning [9118-42]

$X$. Chen, Southern Univ. and A\&M College (United States)

\section{BIOMEDICAL CONCERNS AND S\&T APPROACHES}

9118 OT Neo-angiogenesis metabolic biomarker of tumor-genesis tracking by infrared joystick contact imaging in personalized homecare system (Invited Paper) [91 18-14]

H. Szu, The Catholic Univ. of America (United States); P. Hoekstra, Therma-Scan, Inc. (United States); J. Landa, BriarTek, Inc. (United States); N. A. Vydelingum, National Institutes of Health (United States)

9118 OU Authentication, privacy, security can exploit brainwave by biomarker (Invited Paper) [91 18-27]

J. Jenkins, George Mason Univ. (United States); C. Sweet, George Mason Univ. (United States) and Loft Mind, Inc. (United States); J. Sweet, Loft Mind, Inc. (Germany); S. Noel, George Mason Univ. (United States); H. Szu, The Catholic Univ. of America (United States)

9118 OV Heart rate variability (HRV): an indicator of stress [9118-28]

B. Kaur, J. J. Durek, B. L. O'Kane, U.S. Army Night Vision \& Electronic Sensors Directorate (United States); N. Tran, S. Moses, M. Luthra, V. N. Ikonomidou, George Mason Univ. (United States)

9118 OW Impact of human emotions on physiological characteristics [9118-29] P. Partila, M. Voznak, T. Peterek, M. Penhaker, V. Novak, J. Tovarek, M. Mehic, VšBTechnical Univ. of Ostrava (Czech Republic); L. Vojtech, Czech Technical Univ. in Prague (Czech Republic)

$91180 X \quad$ Neural network classifier of attacks in IP telephony [91 18-30]

J. Safarik, M. Voznak, M. Mehic, P. Partila, M. Mikulec, VŠB-Technical Univ. of Ostrava (Czech Republic)

9118 OY Predictive model for determining the quality of a call [9118-31]

M. Voznak, J. Rozhon, P. Partila, J. Safarik, M. Mikulec, M. Mehic, VŠB-Technical Univ. of Ostrava (Czech Republic)

LESSONS LEARNED FROM NONLINEAR LIFE SYSTEM OF SYSTEMS

911810 Using computer algebra and SMT solvers in algebraic biology [9118-32]

M. Pineda Osorio, Univ. EAFIT (Colombia) 
911811 Telescopic multi-resolution augmented reality [9118-33]

J. Jenkins, George Mason Univ. (United States); C. Frenchi, Christopher Newport Univ.

(United States); H. SzU, The Catholic Univ. of America (United States)

911812 Verification of the performance of Artificial Neural Networks (ANNs) versus Partial Least Squares (PLS) for spectral interference correction in optical emission spectrometry (Invited Paper) [9118-34]

Z. Li, X. Zhang, V. Karanassios, Univ. of Waterloo (Canada)

911813 Analyzing toys models of Arabidopsis and Drosophila using Z3 SMT-LIB [91 18-35]

M. Rodríguez Vega, Univ. EAFIT (Colombia)

911814 Solving a discrete model of the lac operon using Z3 [9118-36]

N. A. Gutierrez, Univ. EAFIT (Colombia)

911815 Using the Tutte polynomial to analyze the structure of the benzodiazepines [9118-37]

J. J. Cadavid Muñoz, Univ. EAFIT (Colombia)

911816 Analytical resolution of the reactive diffusion equation for transient electronics including materials whose porosity value changes in terms of their thickness [91 18-38]

A. Vargas Toro, Univ. EAFIT (Colombia)

911817 A model of the immune-compatibility using the install problem in computer science [9118-39]

F. Díaz , Univ. EAFIT (Colombia)

911818 Improving the efficiency of nonparametric entropy estimation [9118-41]

E. A. Timofeev, Yaroslavl State Univ. (Russian Federation); A. Kaltchenko, Wilfrid Laurier Univ. (Canada)

911819 Efficiency of nearest neighbor entropy estimators for Bernoulli measures [91 18-40]

E. A. Timofeev, Yaroslavl State Univ. (Russian Federation); A. Kaltchenko, Wilfrid Laurier Univ. (Canada)

Author Index 


\section{Conference Committee}

Symposium Chair

David A. Whelan, Boeing Defense, Space, and Security (United States)

Symposium Co-chair

Wolfgang Schade, Technische Universität Clausthal (Germany) and

Fraunhofer Heinrich-Hertz-Institut (Germany)

Conference Chair

Harold H. SzU, U.S. Army Research Office (United States)

Conference Co-chair

Liyi Dai, U.S. Army Research Office (United States)

Conference Program Committee

Shun-ichi Amari, RIKEN (Japan)

Richard G. Baraniuk, Rice University (United States)

John J. Benedetto, University of Maryland, College Park (United States)

Henry Chu, University of Lovisiana at Lafayette (United States)

Ronald R. Coifman, Yale University (United States)

John Daugman, University of Cambridge (United Kingdom)

David Donohoe, Stanford University (United States)

Ronald G. Driggers, U.S. Naval Research Laboratory (United States)

Jide Familoni, U.S. Army Night Vision \& Electronic Sensors Directorate (United States)

Fredric M. Ham, Florida Institute of Technology (United States)

Yutaka Hata, University of Hyogo (Japan)

Charles C. Hsu, Trident Systems Inc. (United States)

Tzyy-Ping Jung, University of California, San Diego (United States)

Marc W. Kirschner, Harvard Medical School (United States)

Keith A. Krapels, U.S. Army Night Vision \& Electronic Sensors Directorate (United States)

Horacio Lamela, Universidad Carlos III de Madrid (Spain)

Joseph S. Landa, BriarTek, Inc. (United States)

Douglas A. Lauffenburger, Massachusetts Institute of Technology

(United States)

Soo-Young Lee, KAIST (Korea, Republic of) 
Kevin W. Lyons, National Institute of Standards and Technology

(United States)

Anke D. Meyer-Baese, The Florida State University (United States)

Uwe Meyer-Baese, The Florida State University (United States)

Francesco Carlo Morabito, Università Mediterranea di Reggio

Calabria (Italy)

Hiroshi Nakajima, OMRON Corporation (Japan)

Hyung-Min Park, Sogang University (Korea, Republic of)

Kitt C. Reinhardt, Air Force Office of Scientific Research

(United States)

Zuowei Shen, National University of Singapore (Singapore)

Metin Sitti, Carnegie Mellon University (United States)

Jan-Olov Stromberg, Royal Institute of Technology (Sweden)

John Tangney, Office of Naval Research (United States)

Emmanuel Vincent, IRISA / INRIA Rennes (France)

Nadarajen A. Vydelingum, National Institutes of Health

(United States)

Lipo Wang, Nanyang Technological University (Singapore)

Olaf Wolkenhaver, Universität Rostock (Germany)

Donald C. Wunsch II, Missouri University of Science and Technology

(United States)

Ning Xi, Michigan State University (United States)

Takeshi Yamakawa, Fuzzy Logic Systems Institute (Japan)

Yiping Zhao, The University of Georgia (United States)

Yufeng Zheng, Alcorn State University (United States)

Xiaowei Zhuang, Harvard University (United States)

Session Chairs

1 Large Data Analyses Pioneer Award

Keith A. Krapels, U.S. Army Night Vision \& Electronic Sensors

Directorate (United States)

Harold Szu, U.S. Army Research Office (United States)

2 Large Data Analyses

Keith A. Krapels, U.S. Army Night Vision \& Electronic Sensors

Directorate (United States)

Harold Szu, U.S. Army Research Office (United States)

3 Nano-engineering Pioneer Award

David H. Gracias, Johns Hopkins University (United States)

Yiping Zhao, The University of Georgia (United States)

$4 \quad$ Nano-engineering

Ritesh Agarwal, The University of Pennsylvania (United States)

Kai-Dee Chu, U.S. Dept. of Homeland Security (United States) 
5 Compressive Sampling Pioneer Award

Harold H. Szu, U.S. Army Research Office (United States)

6 Pre-CS vs Post-CS Image Processing

Francois Lalonde, National Institutes of Health (United States)

Nitin Gogtay, National Institutes of Health (United States)

7 Unsupervised Learning ICA Pioneer Award

Soo-Young Lee, KAIST (Korea, Republic of)

Hiroshi Sawada, Nippon Telegraph and Telephone Corporation (Japan)

8 Unsupervised Brain Imaging

Soo-Young Lee, KAIST (Korea, Republic of)

Harold H. Szu, U.S. Army Research Office (United States)

9 Biomedical Wellness Pioneer Award

Weichuan Yu, Hong Kong University of Science and Technology (Hong Kong, China)

Soo-Young Lee, KAIST (Korea, Republic of)

10 Biomedical Concerns and S\&T Approaches

Weichuan Yu, Hong Kong University of Science and Technology (Hong Kong, China)

Soo-Young Lee, KAIST (Korea, Republic of)

11 Systems Biology Pioneer Award

Nadarajen A. Vydelingum, National Institutes of Health (United States)

Anke Meyer-Bäse, The Florida State University (United States)

12 Lessons Learned from Nonlinear Life System of Systems

Nadarajen A. Vydelingum, National Institutes of Health (United States)

Scott Fraser, University of Southern California (United States) 


\section{Introduction}

Baltimore Maryland, Inner Harbor Convention Center - This year's exciting conference proceeding features frontier S\&T research in Human Components Compressive Sensing, ICA, Nano-engineering, Biomedical Wellness Engineering, and System Biology. The Wavelet 'sensory system' Pioneer Award was folded into a new and emerging category called Large Data Analysis. Through the tremendous contributions from authors, presenters, and attendees, new ideas and technologies can be carried to the world and serve the aging global village.

Historically, our section has been part of the SPIE Defense, Security and Sensing Symposium, and is now highlighted in the brand new Sensing Technology + Applications section (STA). The conference proceedings will serve as a wonderful summary of the work presented this year, but nothing can replace physically attending and interacting with our talented scientists and investigators. The Pioneer Awardees for this year were selected by past recipients, and the nomination and selection committee was chaired by the recipients listed below. The 2014 recipients

of the following pioneer awards will serve as the nomination selection committee chair or co-chair for next year's conference:

The 2014 Pioneer Award recipients are:

- Compressive Sampling Pioneer Award, Michael Lustig, University of California, Berkeley

- Large Data Analysis Pioneer Award, John Daugman, University of Cambridge

- Unsupervised Learning ICA Pioneer Award, Jong-Hwan Jay Lee, Korea University

- Nano-engineering Pioneer Award, Chair: Ritesh Agarwal, University of Pennsylvania

- Biomedical Wellness Pioneer Award, Chair: Elisa Konpfagou, Colombia University

- Systems Biology Pioneer Award, Chair: Scott Fraser, University of Southern California

We thank you for making 2014 a successful and memorable year, and encourage past, present, and future associates to participate in the knowledge discovery and sharing through SPIE.

www.ica-wavelet.org

Harold H. SzU

Liyi Dai 